\title{
Evidence of hypoxic foraging forays by yellow perch (Perca flavescens) and potential consequences for prey consumption
}

\author{
JAMES J. ROBERTS*,+, PAUL A. GRECAY ${ }^{\ddagger}$, STUART A. LUDSIN $^{\S}$ ^, STEVE A. POTHOVEN**, \\ HENRY A. VANDERPLOEG ${ }^{\S}$ AND TOMAS O. HÖÖK*,++ \\ *School of Natural Resources and Environment-Cooperative Institute for Limnology and Ecosystems Research, University of Michigan, \\ Ann Arbor, MI, U.S.A. \\ ${ }^{\dagger}$ Department of Fish Wildlife and Conservation Biology, Colorado State University, Fort Collins, CO, U.S.A. \\ ${ }^{\ddagger}$ Department of Biological Sciences, Salisbury University, Salisbury, MD, U.S.A. \\ ${ }^{\S}$ Great Lakes Environmental Research Laboratory-National Oceanic and Atmospheric Administration, Ann Arbor, MI, U.S.A. \\ "The Ohio State University, Department of Evolution, Ecology, and Organismal Biology, Aquatic Ecology Laboratory, Columbus, OH, \\ U.S.A. \\ **Great Lakes Environmental Research Laboratory-National Oceanic and Atmospheric Administration: Lake Michigan Field Station, \\ Muskegon, MI, U.S.A. \\ ${ }^{++}$Department of Forestry and Natural Resources, Purdue University, West Lafayette, IN, U.S.A.
}

\section{SUMMARY}

1. Previous studies in a variety of ecosystems have shown that ecologically and economically important benthic and bentho-pelagic fishes avoid hypoxic $\left(<2 \mathrm{mg} \mathrm{O}_{2} \mathrm{~L}^{-1}\right)$ habitats by moving vertically or horizontally to more oxygenated areas. While avoidance of hypoxic conditions generally leads to a complete shift away from preferred benthic prey, some individual fish continue to consume benthic prey items in spite of bottom hypoxia, suggesting complex habitat utilisation and foraging patterns. For example, Lake Erie yellow perch (Perca flavescens) continue to consume benthic prey, despite being displaced vertically and horizontally by hypolimnetic hypoxia.

2. We hypothesised that hypolimnetic hypoxia can negatively affect yellow perch by altering their distribution and inducing energetically expensive foraging behaviour. To test this hypothesis, we used drifting hydroacoustics and trawl sampling to quantify water column distribution, sub-daily vertical movement and foraging behaviour of yellow perch within hypoxic and normoxic habitats of Lake Erie's central basin during August-September 2007. We also investigated the effects of rapid changes in ambient oxygen conditions on yellow perch consumption potential by exposing yellow perch to various static and fluctuating oxygen conditions in a controlled laboratory experiment.

3. Our results indicate that, while yellow perch in general avoid hypoxic conditions, some individuals undertake foraging forays into hypoxic habitats where they experience greater fluctuations in abiotic conditions (pressure, temperature and oxygen concentration) than at normoxic sites. However, laboratory results suggest short-term exposure to low oxygen conditions did not negatively impact consumption potential of yellow perch.

4. Detailed understanding of sub-daily individual behaviours may be crucial for determining interactive individual- and ecosystem-level effects of stressors such as hypoxia.

Keywords: anoxia, bioenergetics, eutrophication, Great Lakes, movement behaviour

\footnotetext{
Correspondence: James J. Roberts, Department Fish, Wildlife and Conservation Biology, Colorado State University, 1474 Campus Delivery, Fort Collins, CO 80526, U.S.A. E-mail: jjrobert@colostate.edu

Tomas O. Höök, Department of Forestry and Natural Resources, Purdue University, 195 Marstellar Street, West Lafayette, IN 47907, U.S.A. E-mail: thook@purdue.edu
} 


\section{Introduction}

Hypoxia $\left(<2 \mathrm{mg} \mathrm{O}_{2} \mathrm{~L}^{-1}\right)$ is a recurring environmental stressor in bottom waters of many marine, estuarine and freshwater systems throughout the world (Diaz, 2001; Diaz \& Rosenberg, 2008) and may simultaneously impact multiple levels of ecological organisation. That is, hypoxia can influence sub-daily foraging and distributional patterns of individual fishes (Rahel \& Nutzman, 1994; Taylor, Rand \& Jenkins, 2007), which in turn may alter population dynamics, community structure and ecosystem dynamics and function (Turner, 2001; Breitburg, 2002; Diaz \& Rosenberg, 2008). A broad range of studies have demonstrated that hypoxia can directly and indirectly influence distributions, foraging and condition of fishes in freshwater (Aku \& Tonn, 1997, 1999; Roberts et al., 2009), estuarine (Pihl, 1994; Eby \& Crowder, 2002; Stierhoff, Targett \& Power, 2009) and coastal marine environments (Craig \& Crowder, 2005; Hazen et al., 2009; Zhang et al., 2009). However, the mechanistic details underlying these responses are often lacking, and Rose et al. (2009) suggested this lack of information on fish exposure and avoidance of hypoxic conditions confounds the development and application of models that predict population-level consequences of hypoxia. Thus, elucidating individual-level consequences of hypoxia is an important first step towards understanding impacts at the population, community or ecosystem level.

Hypoxia can alter the distribution of fishes through avoidance behaviour (Suthers \& Gee, 1986; Aku, Rudstam \& Tonn, 1997; Eby \& Crowder, 2002). For example, Aku et al. (1997) demonstrated in a hypoxic temperate lake that cisco (Coregonus artedi Lesueur) entirely avoided their preferred habitat in the cool hypolimnion. Consequently, avoidance of low oxygen bottom waters may isolate fish from preferred benthic prey, lead to occupation of inferior thermal and optical habitats and expose them to novel sets of predators and prey (Ludsin et al., 2009; Arend et al., 2011). Avoidance behaviours may also compress fishes into smaller areas where inter- and intra-specific densitydependent processes could negatively impact feeding, growth and survival (Eby \& Crowder, 2002; Eby et al., 2005).

While some fishes will completely avoid hypoxic habitats, others may adopt more dynamic habitat utilisation strategies. In systems with a hypoxic bottom layer, some fish species (e.g. central mudminnows Umbra limi Kirtland and anchovies Anchoa spp) will undertake brief foraging forays into hypoxic habitats (Rahel \& Nutzman, 1994; Taylor et al., 2007). Thereby, these fish obtain energetically favourable demersal prey, while limiting exposure to ambient hypoxia and risk of asphyxiation. However, this behaviour may expose fish to rapid changes in ambient conditions such as pressure, temperature and oxygen concentrations and incur energetic costs that may negatively impact growth and condition.

The large central basin of Lake Erie (United States of America and Canada) experiences hypolimnetic hypoxia during late summer (Burns et al., 2005; Hawley et al., 2006; Rucinski et al., 2010). Because the hypolimnion of Lake Erie's central basin (LECB) provides a cool thermal habitat and energetically favourable prey that many fishes consume during normoxic conditions, hypoxia could potentially reduce habitat quality for benthic and cool water fishes and result in reduced growth (Roberts et al., 2009; Arend et al., 2011). For example, yellow perch (Perca flavescens Mitchill), an ecologically important benthic species that also supports valuable recreational and commercial fisheries (Ryan et al., 2003), could be negatively affected by hypolimnetic hypoxia in LECB. In fact, laboratory studies suggest yellow perch consumption (Roberts et al., 2011) and growth (Carlson, Blocher \& Herman, 1980) are negatively affected by continuous exposure to hypoxic conditions. Also, previous field studies have demonstrated that yellow perch migrate vertically or horizontally to avoid low oxygen concentrations (Roberts et al., 2009; Vanderploeg et al., 2009b), perhaps to minimise negative impacts on growth and survival (Arend et al., 2011). Interestingly, however, some individual yellow perch continue to forage on benthic prey (e.g. Chironomidae larvae) despite residing above the hypoxic bottom layer and up to $8 \mathrm{~m}$ from the lake bottom (Roberts et al., 2009). These results suggest that yellow perch in LECB undertake foraging forays into hypolimnetic hypoxic waters.

Herein, we describe a study to (i) quantify diverse foraging behaviour by yellow perch in response to hypolimnetic hypoxia and (ii) evaluate potential costs of hypolimnetic foraging forays on consumption potential. Specifically, we conducted hydroacoustic and trawl surveys to capture spatial variation in the water column distribution, diet and short-term vertical movement behaviour of yellow perch in relation to hypoxia. Moreover, to quantify effects on consumption, we conducted a controlled laboratory experiment to expose yellow perch to various static and fluctuating oxygen conditions. Collectively, through our field surveys and laboratory experiment, we evaluate the hypothesis that hypolimnetic hypoxia can negatively affect yellow perch by altering their distribution and inducing energetically expensive foraging forays. 


\section{Methods}

We sampled LECB (Fig. 1) three times during the peak of hypoxia in 2007, on board the $\mathrm{R} / \mathrm{V}$ Laurentian (August and September) and Lake Guardian (September). We visited seven sites with a stratified water column and either a normoxic $\left(>2 \mathrm{mg} \mathrm{L}^{-1}\right)$ or hypoxic $\left(\leq 2 \mathrm{mg} \mathrm{L}^{-1}\right)$ hypolimnion and four sites with a normoxic unstratified water column (Table 1). At each site, we collected physical, chemical and biological data along a 5-km east-west transect (for examples of sampling sites, see Pothoven et al., 2009; Vanderploeg et al., 2009a and Roberts et al., 2009). However, given sampling constraints, we did not collect all information described below at each sampling site (Table 1).

\section{Habitat conditions and yellow perch prey consumption}

To quantify abiotic environmental conditions (temperature, dissolved oxygen and photosynthetically active radiation) of the entire water column, we conducted vertical casts with a sensor package consisting of a SeaBird CTD, fluorometer and dissolved oxygen sensor (Sea-Bird Electronics, Bellevue, WA, U.S.A.; see Vanderploeg et al., 2009a for sensor specifications). Casts were conducted once per 24-h sampling period and collected data at c. 0.03-m depth intervals at the endpoints and midpoint of each east-west $5-\mathrm{km}$ station transect (i.e. $n=3$ casts per sampling site). For analyses, measurements were grouped into 1-m depth bins. We used these data to split the water column into two isothermal layers, above (epilimnion) and below (hypolimnion) the thermocline. We then used the layer-specific measures of depth, temperature and dissolved oxygen to represent depthspecific abiotic conditions within each of these layers.

We sampled the potential prey of yellow perch, including both zooplankton and benthic macroinvertebrates. Zooplankton samples were collected with a $0.5-\mathrm{m}$ diameter, $64-\mu \mathrm{m}$ mesh net at six sites (Table 1). Two vertical net tows were conducted at each site and after collection zooplankton were narcotised with Alka-Seltzer and preserved in a sugar-buffered $2 \%$ formaldehyde solution. Zooplankton prey were counted and identified in the laboratory using methods described in Vanderploeg et al. (2009b). We subsequently grouped zooplankton into coarse taxonomic groups for analysis.

We collected potential benthic prey with a Ponar grab sampler (250- $\mu \mathrm{m}$ mesh; $0.047-\mathrm{m}^{2}$ sampling area) once during each 24 -h sampling period at six sites (Table 1). Samples were collected in triplicate at the endpoints and midpoint of each east-west site transect (i.e. $n=9$ grabs per site) and concentrated in 5\% formalin with rose bengal stain (Thermo Fisher Scientific Inc., Asheville, NC, U.S.A.) to facilitate subsequent laboratory analysis.

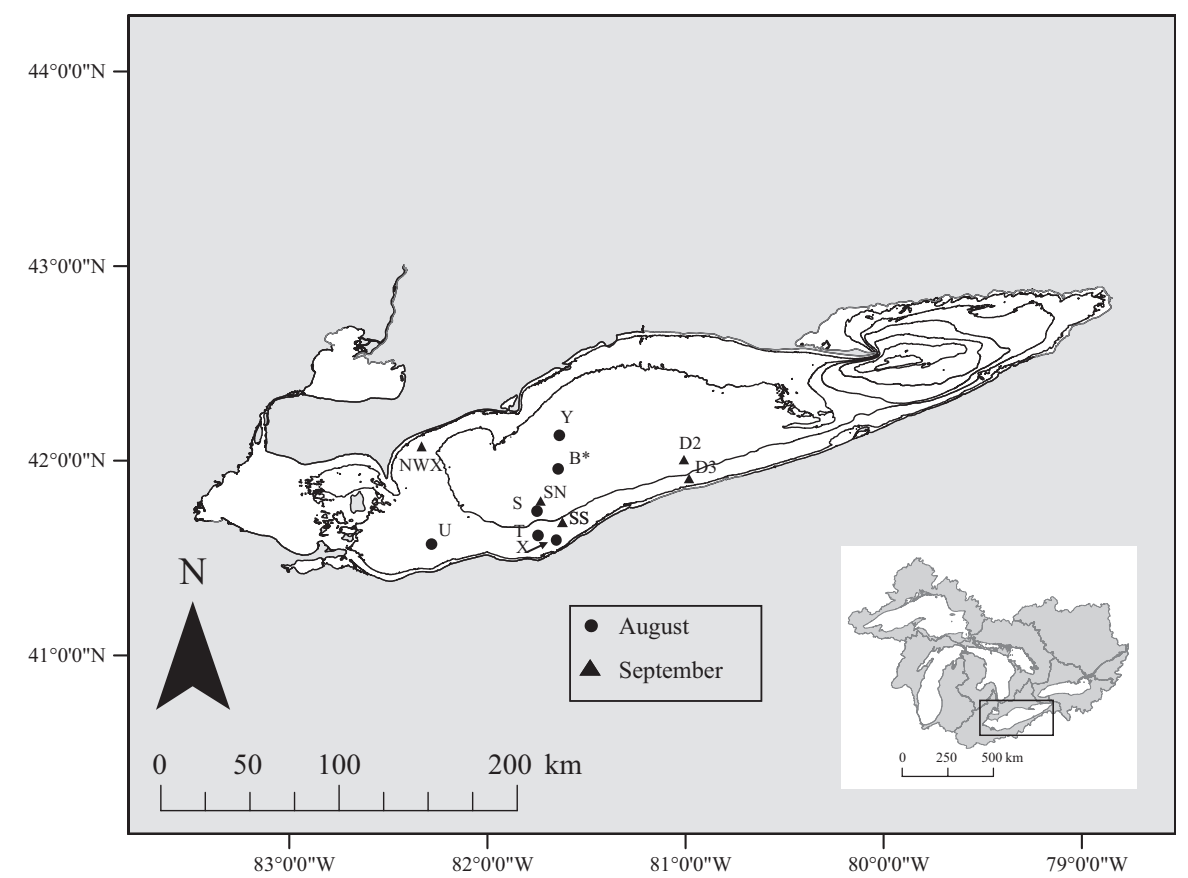

Fig. 1 Location of Lake Erie within the Laurentian Great Lakes and sites sampled during August and September 2007. Lake Erie bathymetry is depicted with 10-m depth contours. *Site B was sampled during both August and September. 
Table 1 Mean abiotic habitat characteristics of sites sampled in Lake Erie's central basin during summer 2007. Sites are categorised as: Hypoxic $(\mathrm{H})$, Normoxic $(\mathrm{N})$ and Unstratified $(\mathrm{U})$. Groupings based on the presence $(\mathrm{H}$ or $\mathrm{N}$ ) or absence $(\mathrm{U})$ of a thermocline and (if thermocline is present) hypolimnetic dissolved oxygen (DO) concentration ( $\left.>2 \mathrm{mg} \mathrm{L}^{-1}=\mathrm{N}, \leq 2 \mathrm{mg} \mathrm{L}^{-1}=\mathrm{H}\right)$. The absence of any vertical thermal structure at unstratified sites is denoted by ' - '. Site-specific sampling procedures included benthic and zooplankton prey sampling (BZ), trawling and yellow perch diet analysis (TrD), trawling (Tr), drifting (DA) and transect (TA) hydroacoustics

\begin{tabular}{|c|c|c|c|c|c|c|c|c|c|}
\hline Month & Site & $\begin{array}{l}\text { Depth } \\
(\mathrm{m})\end{array}$ & $\begin{array}{l}\text { Epilimnion } \\
\text { temp. }\left({ }^{\circ} \mathrm{C}\right)\end{array}$ & $\begin{array}{l}\text { Epilimnion } \\
\text { DO }\left(\mathrm{mg} \mathrm{L}^{-1}\right)\end{array}$ & $\begin{array}{l}\text { Thermocline } \\
\text { depth }(\mathrm{m})\end{array}$ & $\begin{array}{l}\text { Hypolimnion } \\
\text { temp. }\left({ }^{\circ} \mathrm{C}\right)\end{array}$ & $\begin{array}{l}\text { Hypolimnion } \\
\text { DO }\left(\mathrm{mg} \mathrm{L}^{-1}\right)\end{array}$ & $\begin{array}{l}\text { Sampling } \\
\text { Procedure }\end{array}$ & Category \\
\hline \multirow[t]{4}{*}{ August } & B & 24.0 & 23.1 & 7.5 & 15 & 11.8 & 2.1 & $\mathrm{BZ}, \operatorname{TrD}$ & $\mathrm{H}$ \\
\hline & $\mathrm{U}$ & 13.5 & 23.4 & 7.5 & 11 & 20.5 & 4.1 & $\mathrm{BZ}, \operatorname{TrD} \mathrm{DA}, \mathrm{TA}$ & $\mathrm{N}$ \\
\hline & $\mathrm{T}$ & 13.0 & 23.9 & 6.6 & - & - & - & $\operatorname{Tr}^{*}$ & $\mathrm{U}$ \\
\hline & $x$ & 14.0 & 23.8 & 6.9 & - & - & - & $\operatorname{Tr}^{*}$ & $\mathrm{U}$ \\
\hline & $\mathrm{D} 2$ & 21.0 & 20.8 & 6.7 & - & - & - & $\operatorname{Tr}$ & $\mathrm{U}$ \\
\hline & D3 & 17.5 & 20.9 & 6.8 & - & - & - & $\operatorname{Tr}$ & $\mathrm{U}$ \\
\hline & NWX & 16.0 & 22.8 & 7.8 & 14.0 & 21.0 & 5.6 & $\mathrm{DA}$ & $\mathrm{N}$ \\
\hline & $\mathrm{SN}$ & 22.5 & 19.9 & 7.2 & 20 & 12.7 & 1.4 & $\mathrm{BZ}, \mathrm{TrD}, \mathrm{DA}, \mathrm{TA}$ & $\mathrm{H}$ \\
\hline & SS & 18.0 & 21.0 & 6.8 & 18 & 18.6 & 4.5 & $\mathrm{BZ}, \mathrm{TrD}, \mathrm{TA}$ & $\mathrm{N}$ \\
\hline
\end{tabular}

*Only sampled during nighttime.

Benthic samples were processed in the laboratory following previously described methods (Pothoven et al., 2009; Roberts et al., 2009), which consisted of identifying and counting all organisms, measuring the length of up to 30 individuals per coarse taxonomic category (i.e. Chironomidae larvae and pupae, Oligochaeta, Sphaeridae, Dreissena spp. and others), and then using taxon-specific length-mass relationships (e.g. Benke et al., 1999) to calculate taxon-specific biomass density. To quantify Oligochaeta biomass, we measured dry mass of subsampled Oligochaeta pieces from each Ponar sample.

Yellow perch were collected using bottom $(7.6 \mathrm{~m}$ semiballoon: $13 \mathrm{~mm}$ stretched-mesh cod-liner) and mid-water trawls $(9.1 \times 9.1 \mathrm{~m}: 13 \mathrm{~mm}$ stretched-mesh cod-liner $)$ at ten sites (Table 1 and Fig. 1). During a 24-h sampling period, each type of trawl was deployed during daylight and nighttime (mean bottom trawl tow time $=9.5 \mathrm{~min}$; mean mid-water trawl tow time $=19.7 \mathrm{~min}$; Sites $\mathrm{T}$ and $\mathrm{X}$ were only sampled during the nighttime in August). Upon collection, yellow perch and all other species were rapidly enumerated and frozen $\left(-20^{\circ} \mathrm{C}\right)$.

In the laboratory, we quantified yellow perch stomach contents. Individuals were thawed, measured (nearest $1 \mathrm{~mm}$ total length, TL) and weighed (nearest $0.1 \mathrm{mg}$ wet mass) before stomach content analysis. Following the protocol of Roberts et al. (2009), we identified yellow perch stomach contents to the lowest possible taxonomic level using a dissecting microscope and image analysis system. We used taxon-specific length-mass relationships (Rosen, 1981; Culver et al., 1985; Benke et al., 1999) to estimate dry biomass for each taxon and used dry biomass estimates to calculate the proportional composition of each individual's diet. We grouped prey into seven coarse categories for our diet analysis: (i) Chironomidae larvae, (ii) Chironomidae pupae, (iii) other benthos, (iv) Bythotrephes longimanus Leydig, (v) zooplankton and (vi) other (i.e. eggs, fish and unidentifiable organisms). Herein, we only present diet information from the six sites also sampled for potential prey items (Table 1). Moreover, to minimise the effect of individual size on foraging patterns, we only present diet information for yellow perch between 100 and $300 \mathrm{~mm}$ in total length, which corresponds to ages 1-3, the most common size class captured via trawling within LECB (Belore et al., 2007).

\section{Yellow perch distribution}

We used trawling and transect hydroacoustics to determine the aggregate distribution of yellow perch biomass throughout the water column. We acquired hydroacoustic data with a split-beam DTX $120-\mathrm{kHz}$ echosounder (BioSonics Inc., Seattle, WA, U.S.A.) (ping rate of 4 pings s $^{-1}$, $0.4-\mathrm{ms}$ pulse width, and $-130 \mathrm{~dB}$ acquisition threshold) mounted to a tow-body that was located within $1 \mathrm{~m}$ of the water surface and towed across the transect at $<2.5 \mathrm{~m} \mathrm{~s}^{-1}$. We deployed hydroacoustic gear during nighttime to sample fish biomass throughout the water column along many of the $5-\mathrm{km}$ transect sites (because of sampling constraints, we did not perform transect hydroacoustics at site B in August and site NWX in September; Table 1). Simultaneously, we deployed bottom and mid-water trawls (as described above) to determine the fish assemblage (species and size) present at each site, which subsequently facilitated partitioning of hydroacoustic biomass. 
To capture sub-daily vertical movement events of individual yellow perch, we also collected hydroacoustic data while drifting within some of our $5-\mathrm{km}$ transect sites (Table 1). We compared these drifting hydroacoustic data with depth-specific physical data to quantify changes in ambient temperature and dissolved oxygen concentrations experienced by mobile yellow perch. We collected drifting hydroacoustic data using the same transducer, settings and towfish described above for transect hydroacoustic surveys. During drift sampling, our research vessel's engines were off and no anchor was deployed, similar to procedures previously suggested for use in the Great Lakes (Parker-Stetter et al., 2009; Rudstam et al., 2009). We recorded data during dusk ( $\pm 2 \mathrm{~h}$ civil twilight), as previous studies of yellow perch diel foraging patterns within LECB suggested this is the period of greatest food consumption (Hayward et al. 1991). We collected a total of $5.5 \mathrm{~h}$ of drifting hydroacoustic data during 2007 at four hypoxic stratified sites and two normoxic stratified sites (Table 1).

We followed an established Great Lakes protocol for hydroacoustic data processing (Rudstam et al., 2009), using Echoview 4.3 software (EV; Myriax, Hobart, Tas., Australia) to process hydroacoustic data. We scaled echointegrated data using in situ target strength (TS) to calculate fish density (fish $\mathrm{m}^{-3}$ ) across vertical depth layers of 1-m. In addition, we assessed suitability of conditions for estimating in situ TS using the Nv index (Sawada, Furusawa \& Williamson, 1993), with all calculated $\mathrm{Nv}$ values being appropriately below 0.1 (Sawada et al., 1993; Rudstam et al., 2009). We estimated mean in situ TS for all targets between -75 and $-20 \mathrm{~dB}$. We identified single targets using the Single Target Detection Method 2 in EV, with parameter settings recommended by Rudstam et al. (2009): threshold of $-75 \mathrm{~dB}$, pulse length determination level of $6 \mathrm{~dB}$, minimum and maximum normalised pulse lengths of 0.8 and 1.3, maximum beam compensation of $3 \mathrm{~dB}$, and standard deviation of angular position of 0.6 .

We used trawl catches (species composition and TL information) and published TL-TS relationships to identify ranges of TS at each site for yellow perch and other fish species (Suppl. Table S1). The most abundant fishes and the source of their respective TL-TS relationship were gizzard shad (Dorosoma cepedianum Lesueur; Foote, 1987), rainbow smelt (Osmerus mordax Mitchill; Rudstam et al., 2003), yellow perch (obtained from Eurasian perch; Perca fluviatilis Linnaeus; Frouzova et al., 2005) and Moronidae (i.e. white bass Morone chrysops Rafinesque and white perch Morone americana Gmelin; Hartman \& Nagy, 2005). Once site-specific yellow perch TS ranges were deter- mined, we applied these as data filters in all of our hydroacoustic analyses. Then, we used the yellow perch TS-TL relationship to determine the average biomass of each fish (using a length-weight regression) and multiplied the average fish size by the fish density to determine depth-specific volumetric and areal yellow perch biomass.

\section{Effect of fluctuating oxygen on yellow perch consumption rate}

We evaluated the response of yellow perch consumption rates to static and sub-daily fluctuating oxygen concentrations using the experimental system described by Grecay \& Stierhoff (2002) at the University of Delaware, College of Marine and Earth Sciences (Lewes, DE). The experimental system consisted of five recirculating treatments, with ten $11 \mathrm{~L}$ replicate tanks per treatment. Within each treatment, we were able to measure and adjust oxygen concentrations in 30-min time blocks. We controlled treatments via a central computer in which the desired oxygen concentrations for every 30-min time block over $24 \mathrm{~h}$ were set and stored. The experimental system is fully described in Grecay \& Stierhoff (2002) and has been used in previous studies (Stierhoff, Targett \& Grecay, 2003; Stierhoff, Targett \& Miller, 2006).

We obtained yellow perch from aquaculture facilities at Delaware State University and maintained fish on pelletised fish food (Melick aquafeed, 1.5-mm slow sinking pellet) in the laboratory for 30 days under identical temperature and light regimes used in our experiment. We initiated experimental conditions once yellow perch were acclimated, as indicated by regular feeding behaviour within the experimental chambers (i.e. after 5 days within the experimental chambers). We then allowed experimental fish to acclimate to their respective oxygen treatments; during this time, fish were unfed for 2 days. Finally, we conducted feeding trials on days 3-7 (experimental days $1-5$ ).

We compared consumption by yellow perch (age-1; TL


at $20{ }^{\circ} \mathrm{C}$, across five oxygen treatment levels, each with ten replicate fish (i.e. total $n=50$ yellow perch). Our experimental design included two static oxygen treatments (high: $8 \mathrm{mg} \mathrm{L}^{-1}$ and low: $2 \mathrm{mg} \mathrm{L}^{-1}$ ), two diurnally fluctuating oxygen treatments (high-night/low-day $\mathrm{O}_{2}$ and low-night/high-day $\mathrm{O}_{2}$ ) and one rapidly fluctuating treatment (Fig. 2). The rapidly fluctuating treatment included a 30-min transition period from low to high oxygen levels and a 1.5-h transition period from high to low oxygen levels (Fig. 2a-e), as it took longer for oxygen to be stripped from the water column than to return to 

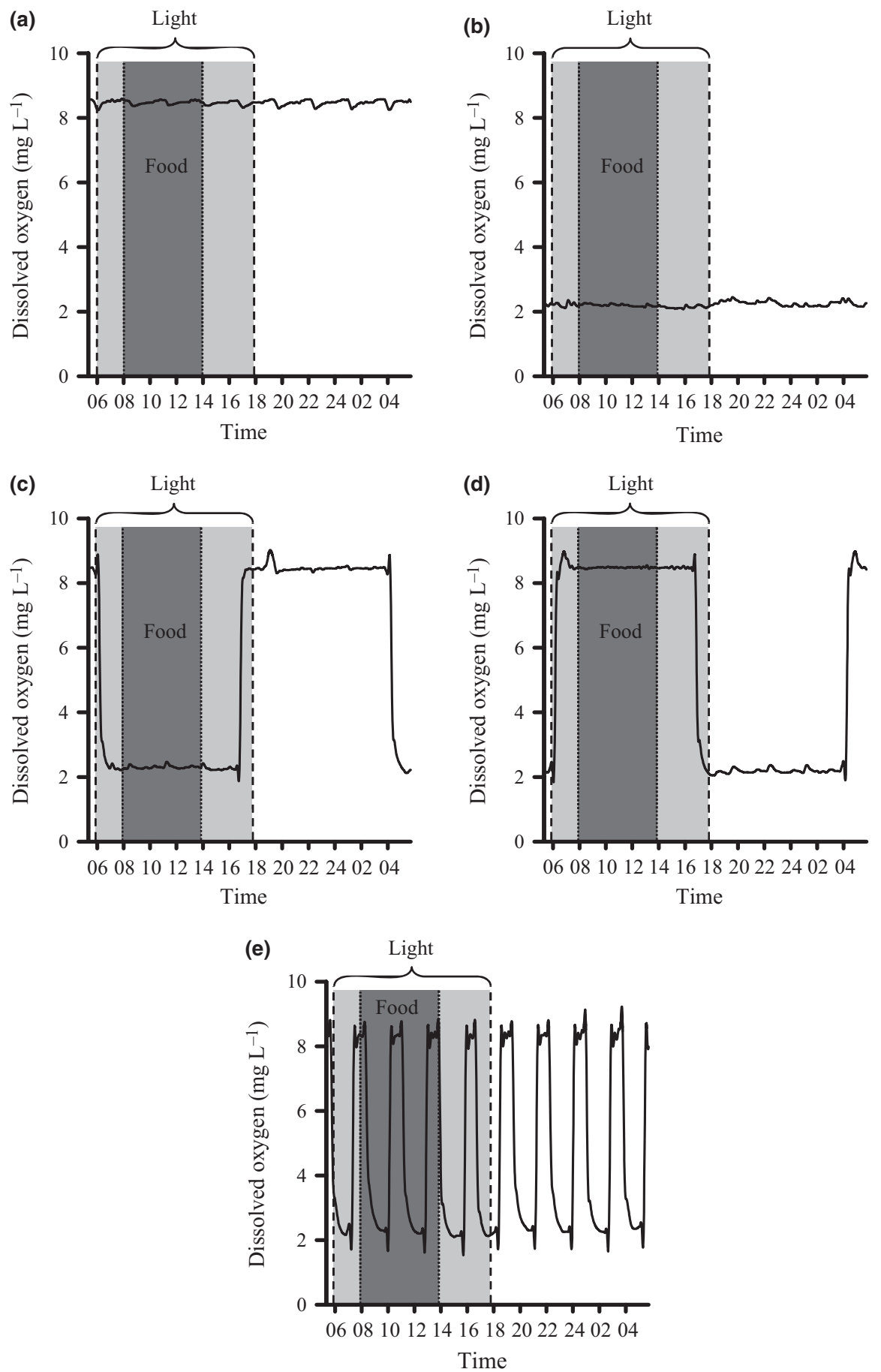

Fig. 2 Example of dissolved oxygen concentrations from five treatment regimes throughout one 24-h period of our consumption experiment. The $6 \mathrm{~h}$ during which food was available to yellow perch is indicated by dark grey shading and $12 \mathrm{~h}$ of light indicated by light grey shading. The five treatments consisted of (a) static high oxygen, (b) static low oxygen, (c) 12-h low-day, high-night oxygen, (d) 12-h high-day, low-night oxygen and (e) rapidly fluctuating oxygen conditions.

equilibrium. We maintained 12:12 hours light regime for all treatments; light during daytime (0600-1800) and dark during nighttime (1800-0600). During the experimental period, we fed yellow perch ad libitum during the day and allowed yellow perch $6 \mathrm{~h}$ (0800-1400) to consume all food
(Fig. 2). We removed and counted unconsumed pellets after $6 \mathrm{~h}$ to quantify fish consumption. We also recorded fish TL (nearest $0.1 \mathrm{~mm}$ ) and wet mass (nearest $0.01 \mathrm{~g}$ ) after the experimental trial to correct for differences in fish size. 


\section{Data analysis}

Available prey and diet analyses. We used one-way analysis of variance (ANOVA) with a post hoc Tukey comparison $(\alpha=0.05)$ to compare mean total zooplankton biomass among sites within each month (mean values from replicate samples taken at each site; $n=2$ per site). We also used a one-way ANOva with a post hoc Tukey comparison $(\alpha=0.05)$ to compare mean total benthic prey biomass among sites (mean values from the endpoints and midpoint of each east-west transect were used as replicates; $n=3$ per site). Dreissena polymorpha Pallas and D. bugensis Andrusov dominated benthic biomass at many sites. However, these invasive dreissenid mussels are not regularly consumed by yellow perch (Roberts et al., 2009). Thus, we compared benthic biomass among sites by first including dreissenid biomass, and then excluding dreissenid biomass. We used the mean proportional diet composition (by biomass) for each site to summarise overall diet patterns.

Yellow perch distributions. We examined spatial variation of yellow perch relative abundance based upon both trawling catch per unit effort (CPUE; number of individuals per min of trawling) and hydroacoustic biomass across the 5-km transects. Given the differential catchability of bottom and mid-water trawls, we only compared yellow perch CPUE within the same sampling gear. We calculated mean CPUE for specific times (day and night) and mean overall site CPUE as the average of day and night CPUE. We used regression analysis to explore relationships between hypolimnetic dissolved oxygen concentration and yellow perch relative abundance, using daytime, nighttime and overall CPUE.

We estimated mean layer-specific (epilimnion and hypolimnion) areal $\left(\mathrm{g} \mathrm{m}^{-2}\right)$ and volumetric $\left(\mathrm{g} \mathrm{m}^{-3}\right)$ total yellow perch hydroacoustic biomass at each site. We summarised transect hydroacoustic datasets obtained during distinct sampling events (i.e. coincident with a single trawling event) and treated these as replicates within a site. We compared mean layer-specific yellow perch hydroacoustic biomass among sites using a oneway ANOvA with a post hoc Games-Howes comparison (to account for unequal variances; $\alpha=0.05$ ).

To analyse our drifting hydroacoustic data, we used the fish-tracking module within EV. Specifically, we identified single targets pertaining to an individual fish's track within the hydroacoustic beam, using parameters previously reported by Johnson et al. (2005). Our drifting hydroacoustic sampling generally captured only a portion of an individual's movement, which could have started, ended or travelled through any of the water column layers (epilimnion or hypolimnion). Output from EV's fishtracking module included the track-specific maximum and minimum TS $(-\mathrm{dB})$ and depth $(\mathrm{m})$. Using physical data collected from our vertical CTD sensor package casts in conjunction with the depth-specific location and range of the individual fish tracks, we quantified the maximum and minimum depth values of each individual fish track and range of temperature and dissolved oxygen associated with each track. For analysis, we assigned tracks that travelled into the hypolimnion at any point as hypolimnetic tracks, whereas we assigned tracks that never crossed into the hypolimnion as epilimnetic tracks. We compared mean changes in depth $(\Delta D)$, ambient temperature $(\Delta T)$ and dissolved oxygen concentration $(\Delta \mathrm{DO})$ among sites: (i) based on all likely yellow perch tracks and (ii) the subset of these tracks that occupied the hypolimnion during a portion of the time observed. We used a one-way ANOVA with a post hoc Tukey comparison $(\alpha=0.05)$ to compare fish track statistics among sites by first including all fish tracks from a particular site and then only including fish tracks that spent time in the hypolimnion.

Effect of fluctuating oxygen on yellow perch consumption rate. We converted our consumption measures from counts of pellets to mass using the average dry mass per pellet, $0.011 \mathrm{~g}$ (SE =0.0004). To standardise for yellow perch size, we divided our consumption measures by the final mass of individual fish. We calculated mean consumption for each individual using experimental days 3-5 because we observed higher and lower consumption on experimental days 1 and 2, respectively. High consumption on day 1 was probably an artefact of starvation during the previous acclimation days, and low consumption on day 2 was likely a compensatory consequence of very high consumption on day 1 . To analyse our laboratory results and test for differences in consumption among treatments, we used a one-way ANOVA with a post hoc Tukey comparison $(\alpha=0.05)$. All statistical analyses were performed using SYSTAT ${ }^{\odot} 12$ software (SYSTAT Software Inc., San Jose, CA, USA).

\section{Results}

The central basin of Lake Erie experienced hypoxic conditions during August and September 2007. During August, offshore areas (i.e. $>14 \mathrm{~m}$ ) of the water column in LECB were stratified with large hypolimnetic regions characterised by hypoxic conditions, including some areas below $1 \mathrm{mg} \mathrm{L}^{-1}$. By contrast, in nearshore areas $(<14 \mathrm{~m}$ 
depth), stratification was rare, and when the water column was stratified, the hypolimnion was normoxic (Table 1). During September, hypolimnetic oxygen conditions were more heterogeneous, with offshore areas that were unstratified, weakly stratified with a normoxic hypolimnion, or strongly stratified with a hypoxic hypolimnion (Table 1). Epilimnetic water temperatures were colder during September than in August; however, within each month, epilimnetic temperatures were fairly consistent across space (Table 1).

\section{Available prey and diet analyses}

Across all sites, copepods comprised the majority of crustacean zooplankton biomass $(67 \%)$, followed by daphnids (19\%). The large predatory B. longimanus was only collected during August (Suppl. Fig. S1A). Total zooplankton biomass did not vary among sites during August $\left(F_{3,4}=0.63 ; P=0.63\right.$; Suppl. Fig. S1A). During September, however, zooplankton biomass was greater at site B than all other sites $\left(F_{2,3}=16.2 ; P=0.03\right.$; Suppl. Fig. S1A). This difference primarily reflected high abundance of copepods at site B during September.

Total benthic biomass ( $\mathrm{g}$ dry mass $\mathrm{m}^{-2}$; including D. polymorpha and D. bugensis, which constituted $98 \%$ of benthic biomass across sites) did not differ among sites during August $\left(F_{3,8}=1.20 ; P=0.19\right)$ or September $\left(F_{2,6}=\right.$ $0.88 ; P=0.46$; Suppl. Fig. S1B). Non-dreissenid benthic biomass, however, varied among sites during August $\left(F_{3,8}=43.27 ; P<0.001\right.$; Suppl. Fig. S1B) when biomass was greatest at site $\mathrm{Y}$ and lowest at sites B and U (Suppl. Fig. S1B). On the other hand, during September, nondreissenid benthic biomass did not differ among sites $\left(F_{2,6}=1.81 ; P=0.24\right.$; Suppl. Fig. S1B).

We analysed the diets of 147 yellow perch from six sites. Owing to the combination of low catches and a large proportion of empty stomachs at some sites, we were unable to achieve balanced sample sizes across sites (Table 2). Nonetheless, we documented that some yellow perch at hypoxic sites consumed benthic prey items. Specifically, at sites with moderately low oxygen levels in August (sites B and S), yellow perch consumed primarily Chironomidae $(72 \%$ and $83 \%$ by biomass respectively), whereas yellow perch only consumed pelagic prey at site $\mathrm{Y}$, which was severely hypoxic with the lowest hypolimnetic DO level larvae (Table 2; Fig. 3). At site U (the only stratified site with a normoxic hypolimnion during August), yellow perch consumed mostly B. longimanus $(52 \%)$, a highly preferred, large-bodied zooplankton species (Bur \& Klarer, 1991; Fig. 3). During September, yellow perch at a hypoxic site (SN) primarily consumed Chironomidae larvae $(97 \%)$, whereas individuals from a



Fig. 3 Proportional composition by biomass of site-specific yellow perch diets collected in Lake Erie during August and September 2007. Hypolimnetic dissolved oxygen concentration $\left(\mathrm{mg} \mathrm{L}^{-1}\right)$ given in parentheses below site name.

Table 2 Yellow perch (YEP) summary statistics for fish total length (TL) and specific diet patterns from Lake Erie's central basin during August and September 2007. Diets are summarised by frequency of occurrence for each diet category and the percentage of yellow perch with empty stomachs for each site and month

\begin{tabular}{|c|c|c|c|c|c|c|c|c|}
\hline Month & Site & $\mathrm{TL}(\mathrm{mm})$ & $\begin{array}{l}\text { Number of YEP } \\
\text { (\% empty) }\end{array}$ & \multicolumn{5}{|c|}{ Frequency of occurrence } \\
\hline \multirow[t]{3}{*}{ August } & B & 132 & $38(65)$ & 0.77 & 0.23 & 0.00 & 0.15 & 0.00 \\
\hline & $S$ & 194 & $8(50)$ & 1.00 & 0.50 & 0.25 & 0.50 & 0.00 \\
\hline & $\mathrm{U}$ & 203 & $36(55)$ & 0.06 & 0.06 & 0.75 & 0.19 & 0.75 \\
\hline \multirow{2}{*}{ September } & $\mathrm{SN}$ & 243 & $5(40)$ & 1.00 & 0.00 & 0.67 & 0.00 & 0.00 \\
\hline & SS & 177 & 55 (53) & 0.10 & 0.10 & 0.90 & 0.05 & 0.10 \\
\hline
\end{tabular}


930 J. J. Roberts et al.

stratified normoxic site (SS) targeted B. longimanus (71\%; Fig. 3). We excluded site B from September diet analyses because we did not capture any yellow perch at this site during September.

\section{Yellow perch distribution}

Trawl collections suggest that horizontal and vertical distributions of yellow perch are influenced by hypolimnetic dissolved oxygen concentrations. Positive relationships between hypolimnetic dissolved oxygen concentration and yellow perch CPUE in bottom trawls were found for overall and nighttime catches (Fig. 4a,c). While mid-water trawl CPUE was not linearly related to hypolimnetic oxygen concentrations, we only captured yellow perch in the mid-water trawl at hypoxic sites (Fig. 4b,d,f).
We were able to determine a range of hydroacoustic target strengths unique to yellow perch at all but two of our thermally stratified sample sites (Suppl. Table S1). Many white perch and white bass of similar sizes to yellow perch were present at sites U and SS, resulting in a target strength range that included both Moronidae and yellow perch (i.e. we could not distinguish between these two taxa at site U and SS; Suppl. Table S1). Our nighttime transect hydroacoustic biomass estimates suggest that across months, yellow perch biomass varied among sites by both volume (epilimnion $-\mathrm{F}_{5}, 17=3.13 ; P=0.03$; hypolimnion $-F_{5,17}=15.95 ; P<0.001$; Fig. 5a) and area (epilimnion $-F_{5,17}=3.37 ; P=0.03$; hypolimnion $-F_{5,17}=$ 7.90; $P=0.001$; Fig. 5b). Proportionally, yellow perch hydroacoustic biomass was greater in the hypolimnion than epilimnion at sites with normoxic conditions, while the opposite was true at hypoxic sites (Fig. 5). Likewise,
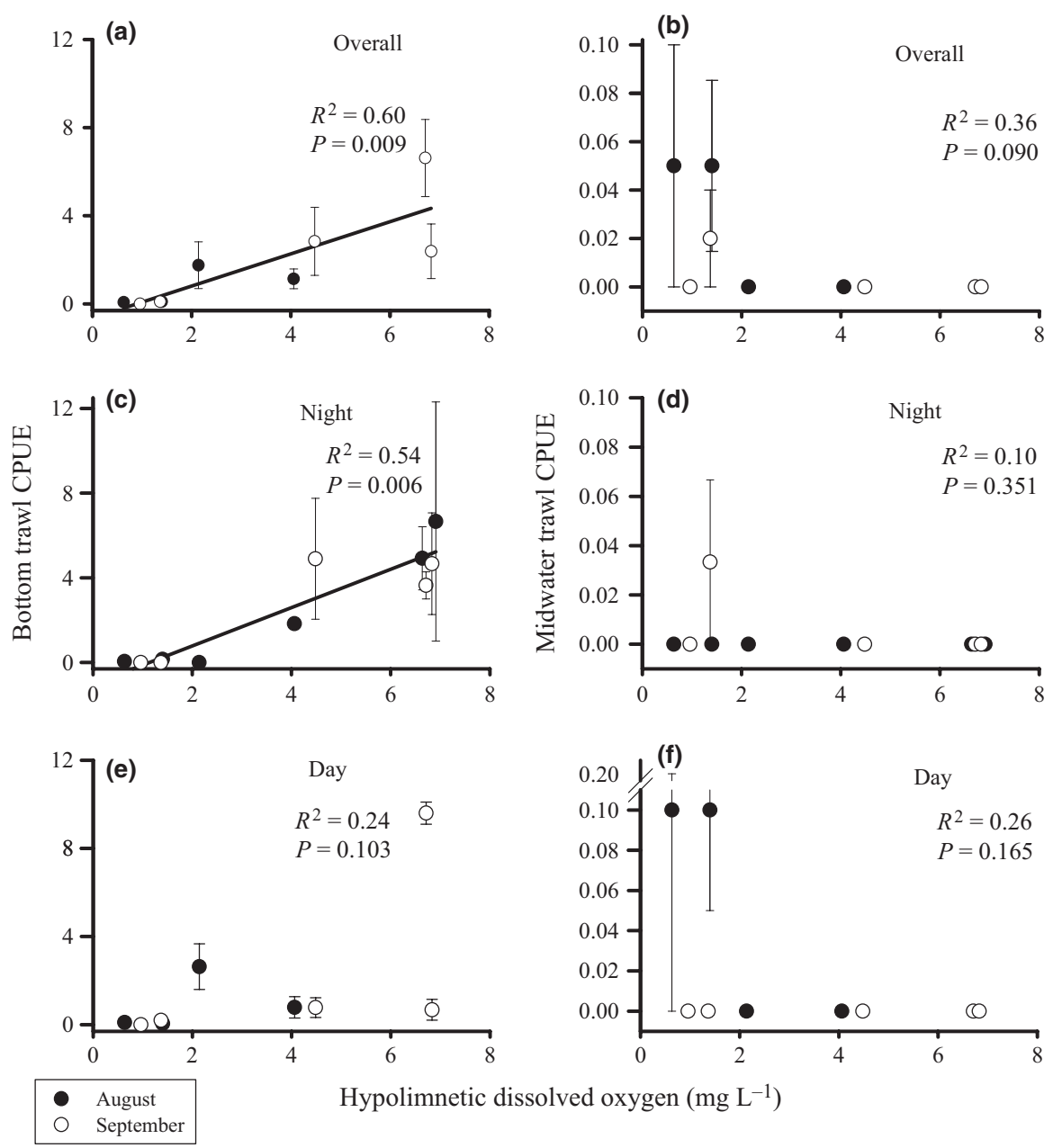

Fig. 4 Relative abundances of yellow perch in central Lake Erie during August and September 2007. Yellow perch-relative abundances are depicted as mean (+SE) catch per unit effort (CPUE; yellow perch per minute of trawling) in bottom trawls (a,c,e) and mid-water trawls (b,d,f), deployed during both day and night $(\mathrm{a}, \mathrm{b})$, only night $(\mathrm{c}, \mathrm{d})$ and only day $(\mathrm{e}, \mathrm{f})$. Trawl results are plotted against hypolimnetic dissolved oxygen concentration $\left(\mathrm{mg} \mathrm{L}^{-1}\right)$, and linear regression results are presented. 

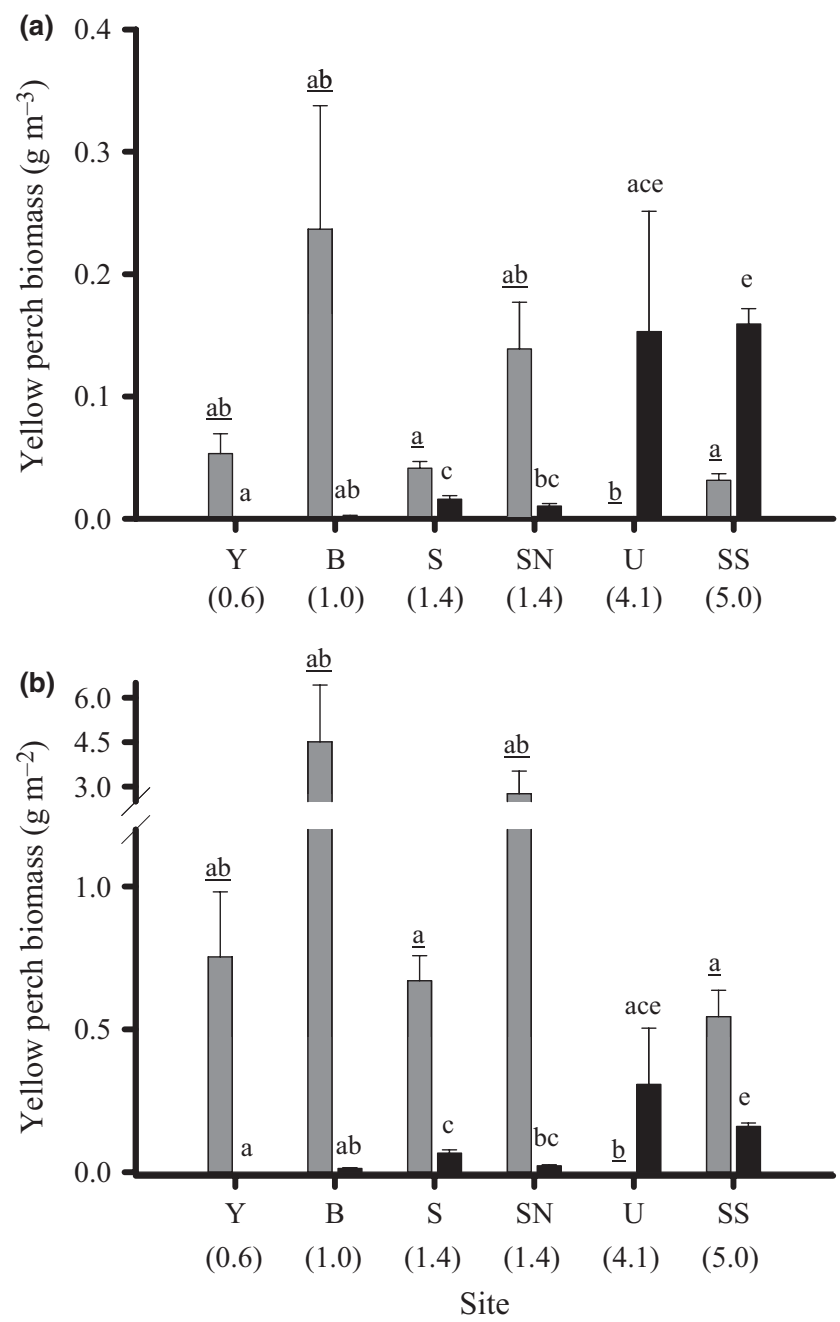

Hypolimnetic DO $\left(\mathrm{mg} \mathrm{L}^{-1}\right)$

Fig. 5 Vertical distribution of mean yellow perch biomass at thermally stratified sites determined from night transect hydroacoustic and trawl estimates collected in Lake Erie's central basin during 2007. Acoustic data are presented within epilimnetic (grey) and hypolimnetic (black) vertical layers (mean $+\mathrm{SE}$ ). Sites are arranged by increasing hypolimnetic dissolved oxygen concentration. Significant differences denoted by unique letters as determined by two one-way ANOVAs (one ANOVA compared epilimnetic biomasses across sites and a second ANOVA compared hypolimnetic biomasses across sites) and post hoc Games-Howes comparison $(\alpha=0.05)$. Vertical distributions of yellow perch biomass are presented by volume $\left(\mathrm{a} ; \mathrm{g} \mathrm{m}^{-3}\right)$ and area $\left(b ; \mathrm{g} \mathrm{m}^{-2}\right)$.

volumetric and areal yellow perch biomass estimates within the hypolimnion at hypoxic sites were less than at normoxic site SS (Fig. 5).

Via drifting hydroacoustics, we observed some fish diving into and ascending out of hypoxic areas (Figs 6a,b), while other fish statically occupied specific areas of the water column (Fig. 6c). We were able to track individual targets for brief periods of time and did not document complete forays into the hypoxic hypolimnion (i.e. a target

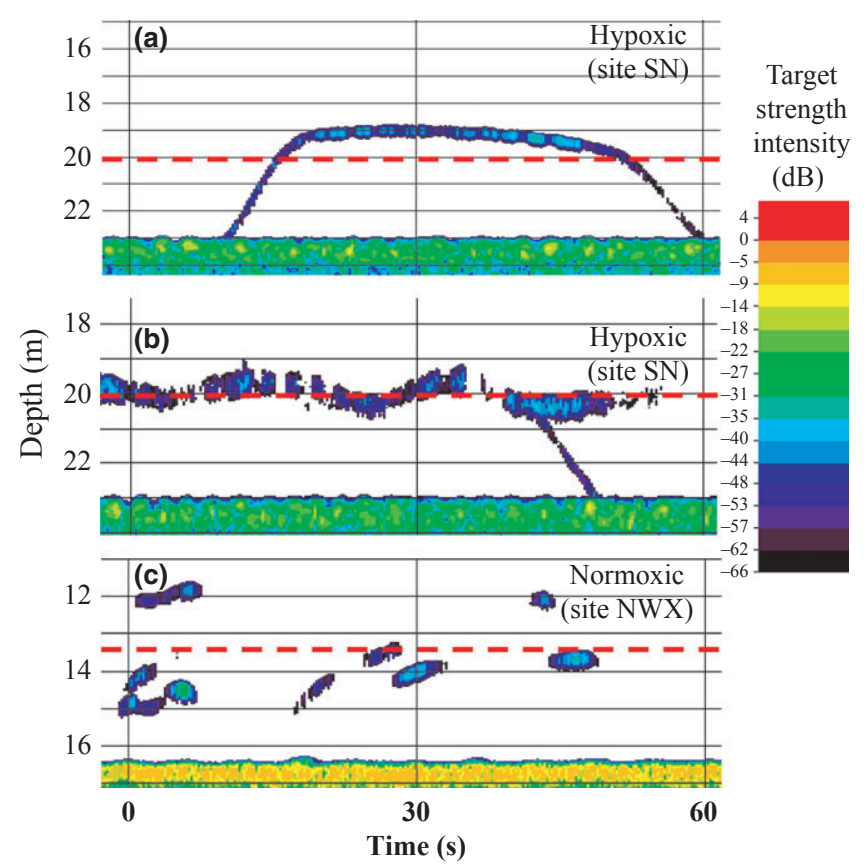

Fig. 6 Sample echograms displaying yellow perch fish tracks from Lake Erie's central basin during 2007. Sample echograms are presented from hypoxic site SN (A\&B) and normoxic site NWX (C). Dashed red lines denote the vertical location of the thermocline within the water column.

swimming into the hypoxic layer, foraging near the bottom, and then returning to normoxic waters above the thermocline). Instead, the tracks that we observed were incomplete in that we only recorded targets diving into or returning from the hypoxic hypolimnetic areas.

While mean $\Delta \mathrm{D}$ did not differ among sites, mean $\Delta \mathrm{T}$ and $\Delta \mathrm{DO}$ varied spatially, but such variation was not consistent across our two water column-specific analyses (Fig. 7). When considering tracks across all depth layers, $\Delta T$ and $\Delta \mathrm{DO}$ were not consistently different among hypoxic and normoxic sites. In contrast, when considering only hypolimnetic tracks, $\Delta T$ was greater at hypoxic sites (B and SN) than normoxic site NWX. Moreover, $\Delta \mathrm{DO}$ was significantly greater at hypoxic site $\mathrm{SN}$ than normoxic site NWX (Fig. 7f). In general, yellow perch swimming into and out of a hypoxic hypolimnion experienced greater changes in temperature and oxygen than fish in areas with a normoxic hypolimnion.

\section{Effect of fluctuating oxygen on yellow perch consumption rate}

During the experimental trials, no fish died and all fish consumed some food. However, oxygen availability affected yellow perch consumption rate $\left(\mathrm{g} \mathrm{g}^{-1}\right.$ day $^{-1}$; Fig. $\left.8 ; F_{4,45}=2.72 ; P=0.04\right)$. Specifically, yellow perch 
All layers

Hypolimnion


Site

Hypolimnetic DO $\left(\mathrm{mg} \mathrm{L}^{-1}\right)$

Fig. 7 Summary of mean (+SE) fish track statistics (change in depth, change in temperature and change in dissolved oxygen concentration) and corresponding one-way ANOVA results. Analyses were performed for tracks within all vertical layers of the water column (a,c,e) and tracks which entered the hypolimnion $(\mathrm{b}, \mathrm{d}, \mathrm{f})$. Sites are arranged in increasing hypolimnetic dissolved oxygen concentration, and bars are coded denoting hypoxic (grey) and normoxic (black) sites. No tracks switched layers at sites $Y$ and U (denoted by ' $\wedge^{\prime}$ ). Statistically significant differences in mean values among sites are indicated by unique combinations of letters which were determined from an ANOVA and post hoc Tukey comparison $(\alpha=0.05)$. We excluded site $S$ from the hypolimnetic analysis since only one track was observed (denoted by ${ }^{\prime * \prime}$ ).

exposed to statically low oxygen concentrations consumed significantly less food than yellow perch exposed to a diurnally varying treatment (i.e. high oxygen during the day and low oxygen during the night; Fig. 8). Importantly, yellow perch experiencing rapidly fluctuating oxygen concentrations fed at the same rate as yellow perch experiencing statically high oxygen concentrations.

\section{Discussion}

Hypoxia has the potential to influence foraging, movement and growth of fish in a variety of ecosystems, including both freshwater and coastal marine (Eby \& Crowder, 2002; Roberts et al., 2009; Vanderploeg et al., 2009b). Both hydroacoustics and trawl data from the Lake Erie central basin demonstrate that fish, including yellow perch, move vertically or horizontally to avoid hypoxic conditions (Vanderploeg et al., 2009a,b). However, based on findings herein, some yellow perch that move vertically to a shallower position within the water column also continue to forage within the hypoxic hypolimnion. In fact, previous studies on yellow perch (Hergenrader \& Hasler, 1966; Roberts et al., 2009) and central mudminnow (Rahel \& Nutzman, 1994) have indicated the potential for 


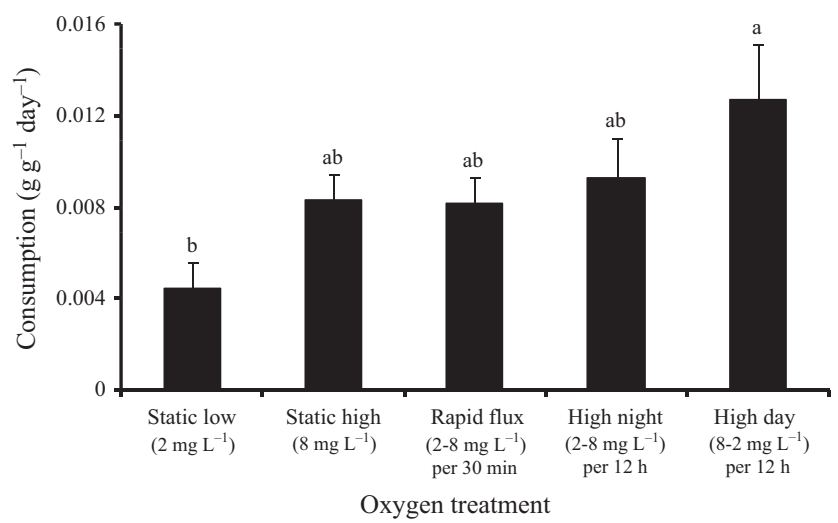

Fig. 8 Mean (+SE) consumption by yellow perch from laboratory trails with different oxygen regimes. Significant differences denoted by unique letters as determined by a one-way ANOvA analysis and post hoc Tukey comparison $(\alpha=0.05)$.

individuals to limit time spent in hypoxic habitats while continuing to forage in these habitats. Our in situ observations of hypoxic foraging forays by yellow perch have provided previously unknown, detailed accounts of this behaviour in natural freshwater systems. Moreover, tracking of hydroacoustic targets quantified the specific abiotic conditions experienced during such behaviours. Not surprisingly, our results demonstrate that yellow perch undertaking hypoxic forays experience pronounced variation in temperature and oxygen conditions. Further, drifting hydroacoustic measures suggest that these behaviours were not rare phenomena, consistent with evidence that yellow perch consume benthic prey items despite hypoxic conditions (Roberts et al., 2009; this study). In addition, although these forays subject individuals to highly variable temperature and oxygen conditions, our laboratory experiment suggests that potential consumption rate is probably not impacted by these rapid fluctuations in ambient oxygen concentrations.

Rose (2000) suggested that understanding fine-scale, spatiotemporal ecological responses to changes in habitat quality is crucial to determining the consequences of environmental changes for fishes, which is particularly important when trying to quantify the impact of hypoxia, as fish can detect and avoid low oxygen concentrations (Kramer, 1987; Wannamaker \& Rice, 2000; Pollock, Clarke \& Dube, 2007). Across a range of aquatic ecosystems, studies have demonstrated that fish will shift distributions in response to hypoxia and thereby either alter prey consumption or undertake foraging forays into hypoxic waters to consume preferred prey. Within marine (Stanley \& Wilson, 2004; Prince \& Goodyear, 2006) and estuarine (Eby \& Crowder, 2002; Taylor \& Rand, 2003; Ludsin et al., 2009) systems, most evidence suggests fish avoid hypoxic habitats and consume alternative prey items (Craig \& Crowder, 2005; Eby et al., 2005; Zhang et al., 2009). However, within the Neuse River estuary, Taylor et al. (2007) reported short forays into hypoxic habitats by anchovies (Anchoa spp.) to forage on preferred zooplankton prey. Similarly, freshwater fish also avoid hypoxic habitats and shift consumption patterns (Aku \& Tonn, 1997; Baldwin, Beauchamp \& Gubala, 2002; Roberts et al., 2009). For example, Aku \& Tonn (1999) reported that cisco increased foraging on pelagic zooplankton when avoiding hypoxic bottom waters, whereas Rahel \& Nutzman (1994) demonstrated that central mudminnows make short forays into hypoxic habitats to forage on preferred prey items. Collectively, these studies suggest that across very different aquatic systems (i.e. coastal marine, estuarine and lentic freshwater), fishes respond to hypoxia in a fairly consistent manner.

Patterns of yellow perch diving into the hypoxic hypolimnion to forage varied spatially among sites (even among hypoxic sites). With hydroacoustics, there is a limited ability to distinguish between the bottom of a water body and individual fish directly on the bottom, and this limitation may partially contribute to spatial inconsistencies in diving patterns. That is, some yellow perch in the hypolimnion may have been difficult to detect, limiting our ability to document the frequency of yellow perch diving behaviour. In addition, variation in hypolimnetic foraging forays among sites probably reflects a combination of abiotic (temperature, dissolved oxygen and hypolimnetic thickness) and biotic factors (pelagic prey, benthic prey and fish assemblage) that influence the profitability of diving behaviour. For example, at sites with extremely low hypolimnetic hypoxia (e.g. site $\mathrm{Y}$ ), we did not find evidence of benthic foraging, which may suggest forays into hypoxic habitat may cease as DO levels approach anoxic levels (i.e. c. $0 \mathrm{mg} \mathrm{L}^{-1}$ ).

The diving behaviour of large pelagic marine fishes has been reported by detailed telemetry studies (Kraus \& Rooker, 2007; Schaefer, Fuller \& Block, 2007; Hays et al., 2009). However, only limited insights into mechanisms regulating these behaviours exist for fishes. A study of Stellar sea lions (Eumetopias jubatus Schreber) suggests diving behaviour is regulated synergistically by resources and predators (Frid et al., 2009). While such studies provide important insights to potential mechanisms regulating yellow perch hypoxic foraging behaviour, more detailed information on the fine-scale characteristics and associated energetic costs and benefits are required to fully understand and predict these behaviours.

Hypolimnetic hypoxic foraging forays by yellow perch in LECB seem adaptive, given that rapid changes in 
ambient oxygen levels appear to only have minor effects on yellow perch consumption potential (per our experiment), and benthic macroinvertebrates (e.g. Chironomidae larvae) are relatively large prey that have a higher energy density (3138 J g wet ${ }^{-1}$ ) than zooplankton $\left(2,510 \mathrm{~J} \mathrm{~g} \mathrm{wet}^{-1}\right.$; Schaeffer et al., 1999). Nonetheless, the ability to tolerate short-term fluctuations in oxygen concentrations seems to be context dependent. While we observed that yellow perch will undertake long-distance (up to $6 \mathrm{~m}$ ) feeding forays into the hypoxic hypolimnion, we did not observe this behaviour at sites with extreme hypoxia. Moreover, Suthers \& Gee (1986) showed that juvenile yellow perch in a freshwater prairie marsh system actively avoid diel cycling hypoxic conditions.

Our experimental results are somewhat surprising in that we documented no difference in consumption between static normoxic conditions and fluctuating DO conditions. However, our experimental results are consistent with a similar study by Carlson et al. (1980), who exposed yellow perch to much smaller diel fluctuations in DO $\left( \pm 1.0-1.5 \mathrm{mg} \mathrm{L}^{-1}\right.$ compared to our $\left.\pm 6.0 \mathrm{mg} \mathrm{L}^{-1}\right)$ and as with our results, only found differences in growth between treatments with the highest $\left(6.5 \mathrm{mg} \mathrm{L}^{-1}\right)$ and lowest $\left(2 \mathrm{mg} \mathrm{L}^{-1}\right)$ mean DO values. Studies of estuarine fishes reveal that fluctuating hypoxic conditions can negatively influence fish growth (Stierhoff et al., 2006) and alter swimming behaviour (Brady, Targett \& Tuzzolino, 2009).

While we evaluated the potential effect of rapidly fluctuating oxygen concentrations, our experiment clearly did not precisely mimic conditions experienced by yellow perch during hypoxic forays in LECB. Through field observations, we were unable to document how long yellow perch forage in the hypoxic hypolimnion within LECB, and hence, we do not know how realistic our fluctuating oxygen treatments are in terms of duration of exposure to hypoxia. Moreover, such forays would lead to sharp changes in not only dissolved oxygen, but also temperature and pressure, and fish undertaking such forays could experience higher energetic costs associated with swimming to greater depths.

Studies investigating the effects of varying temperature on fish suggest fluctuating temperatures may either negatively or positively affect fish's survival and growth. For instance, abrupt and drastic changes in temperature can have acute (i.e. mortality) and chronic negative effects (i.e. stress responses) on fish, with realised responses dependent on the degree of change in temperature and species-specific thermal tolerances (Donaldson et al., 2008). Similarly, the change in pressure associated with these foraging forays may also have energetic costs associated with maintaining buoyancy, common to demersal fishes with swimbladders (Strand, Jorgensen \& Huse, 2005). Conversely, temperature fluctuation also may afford an energetic advantage for some fishes. Bevelhimer \& Adams (1993) used field observations and bioenergetic models to evaluate diel vertical migrations of kokanee salmon (Oncorhynchus nerka Walbaum) and suggested an energetically optimal thermal strategy of foraging at warmer temperatures, where prey is most abundant, and then digesting at cooler temperatures, where metabolic costs are minimised. Our observations, however, suggest yellow perch forage at cooler temperatures (with low oxygen and high prey densities) and digest at warmer temperatures (with high oxygen and low prey densities), making it unlikely that hypoxic hypolimnetic foraging forays are thermally energetically advantageous for yellow perch in LECB.

In summary, as with other fishes (Vanderploeg et al., 2009a,b), a hypoxic hypolimnion in LECB appears to shift yellow perch biomass horizontally (to areas without hypoxic bottom waters) and vertically (higher in the water column; Roberts et al., 2009). Some yellow perch that remain in the hypoxic region continue to exploit benthic prey by undertaking hypolimnetic foraging forays. Experimental results suggest that changes in ambient oxygen concentrations experienced during these forays will have minimal effects on yellow perch consumption potential. While bottom hypoxia is often perceived as a strong negative influence on the entire ecosystem, these observations demonstrate that some species may be able to temper negative consequences through novel, sub-daily movement and foraging behaviour.

Understanding movement responses of fishes to hypoxia is important to fully understand the impact of this limnological phenomenon in LECB and other aquatic systems. Movement patterns of mobile organisms may affect processes regulating populations, food-web structure (Nathan, 2008) and ecosystem function (Flecker et al., 2010). Elucidating movement patterns is also important to the development of models aimed at predicting the consequences of hypoxia across aquatic systems and could serve as important tools for fishery managers. For example, by changing the distribution of yellow perch across Lake Erie, hypoxia could influence the interpretation of fish stock monitoring efforts of US and Canadian agencies (Tyson et al., 2006). Unfortunately, both broad and fine-scale movement patterns are poorly understood for many freshwater fishes (especially in the Great Lakes basin; Landsman et al., 2011). Therefore, further detailed field and laboratory studies aimed at understanding subdaily changes in behaviour, and overall movement patterns of fishes in aquatic ecosystems are imperative 
to further understand and predict the ecological consequences of hypoxia.

\section{Acknowledgments}

We thank all those who helped with field portions of this study, including Greg Jacobs, Brad Utrup, Dave Fanslow, Joann Cavaletto and Aaron Adamack, and those who provided help in the laboratory, including Jennifer Metes, Benjamin Ciotti and Catherine House. We would also like to extend a special thanks to the captains and crew of the $\mathrm{R} / \mathrm{V}$ Laurentian and $\mathrm{R} / \mathrm{V}$ Lake Guardian. Lastly, we thank Tim Targett, who facilitated our use of his dynamic experimental system. Edward Rutherford, Don Scavia and Earl Werner provided comments on a draft of this manuscript. This work was conducted as part of the International Field Years on Lake Erie (IFYLE) program, supported by NOAA-GLERL, NOAA National Sea Grant and the US EPA Great Lakes National Program Office and in part by NOAA Center for Sponsored Coastal Ocean Research grant NA07OAR432000. This manuscript is GLERL-NOAA contribution no. 1613 and EcoFore Lake Erie publication no. 12-002.

\section{References}

Aku P.M.K. \& Tonn W.M. (1997) Changes in population structure, growth, and biomass of cisco (Coregonus artedi) during hypolimnetic oxygenation of a deep, eutrophic lake, Amisk Lake, Alberta. Canadian Journal of Fisheries and Aquatic Sciences, 54, 2196-2206.

Aku P.M.K. \& Tonn W.M. (1999) Effects of hypolimnetic oxygenation on the food resources and feeding ecology of cisco in Amisk Lake, Alberta. Transactions of the American Fisheries Society, 128, 17-30.

Aku P.M.K., Rudstam L.G. \& Tonn W.M. (1997) Impact of hypolimnetic oxygenation on the vertical distribution of cisco (Coregonus artedi) in Amisk Lake, Alberta. Canadian Journal of Fisheries and Aquatic Sciences, 54, 2182-2195.

Arend K.K., Beletsky D., Depinto J.V., Ludsin S.A., Roberts J.J., Rucinski D.K. et al. (2011) Seasonal and interannual effects of hypoxia on fish habitat quality in central Lake Erie. Freshwater Biology, 56, 366-383.

Baldwin C.M., Beauchamp D.A. \& Gubala C.P. (2002) Seasonal and diel distribution and movement of cutthroat trout from ultrasonic telemetry. Transactions of the American Fisheries Society, 131, 143-158.

Belore M., Cook A., Einhouse D., Hartman T., Kayle K., Kenyon R. et al. (2007) Report of the Lake Erie yellow perch task group. p. 51. Great Lakes Fishery Commission.

Benke A.C., Huryn A.D., Smock L.A. \& Wallace J.B. (1999) Length-mass relationships for freshwater macroinvertebrates in North America with particular reference to the southeastern United States. Journal of the North American Benthological Society, 18, 308-343.

Bevelhimer M.S. \& Adams S.M. (1993) A bioenergetics analysis of diel vertical migration by kokanee salmon, Oncorhynchus-nerka. Canadian Journal of Fisheries and Aquatic Sciences, 50, 2236-2349.

Brady D.C., Targett T.E. \& Tuzzolino D.M. (2009) Behavioural responses of juvenile weakfish (Cynoscion regalis) to dielcycling hypoxia: swimming speed, angular correlation, expected displacement, and effects of hypoxia acclimation. Canadian Journal of Fisheries and Aquatic Sciences, 66, 415-424.

Breitburg D. (2002) Effects of hypoxia, and the balance between hypoxia and enrichment, on coastal fishes and fisheries. Estuaries, 25, 767-781.

Bur M.T. \& Klarer D.M. (1991) Prey selection for the exotic cladoceran Bythotrephes cederstroemi by selected Lake Erie fishes. Journal of Great Lakes Research, 17, 85-93.

Burns N.M., Rockwell D.C., Bertram P.E., Dolan D.M. \& Ciborowski J.J.H. (2005) Trends in temperature, secchi depth, and dissolved oxygen depletion rates in the central basin of Lake Erie, 1983-2002. Journal of Great Lakes Research, 31, 35-49.

Carlson A.R., Blocher J. \& Herman L.J. (1980) Growth and survival of channel catfish and yellow perch exposed to lowered constant and diurnally fluctuating dissolved oxygen concentrations. The Progressive Fish-Culturist, 42, 73-78.

Craig J.K. \& Crowder L.B. (2005) Hypoxia-induced habitat shifts and energetic consequences in Atlantic croaker and brown shrimp on the Gulf of Mexico shelf. Marine Ecology Progress Series, 294, 79-94.

Culver D.A., Boucherle M.M., Bean D.J. \& Fletcher J.W. (1985) Biomass of freshwater crustacean zooplankton from length-weight regressions. Canadian Journal of Fisheries and Aquatic Sciences, 42, 1380-1390.

Diaz R.J. (2001) Overview of hypoxia around the world. Journal of Environmental Quality, 30, 275-281.

Diaz R.J. \& Rosenberg R. (2008) Spreading dead zones and consequences for marine ecosystems. Science, 321, 926-929.

Donaldson M.R., Cooke S.J., Patterson D.A. \& Macdonald J.S. (2008) Cold shock and fish. Journal of Fish Biology, 73, 14911530.

Eby L.A. \& Crowder L.B. (2002) Hypoxia-based habitat compression in the Neuse River estuary: context-dependent shifts in behavioral avoidance thresholds. Canadian Journal of Fisheries and Aquatic Sciences, 59, 952-965.

Eby L.A., Crowder L.B., Mcclellan C.M., Peterson C.H. \& Powers M.J. (2005) Habitat degradation from intermittent hypoxia: impacts on demersal fishes. Marine EcologyProgress Series, 291, 249-261.

Flecker A.S., Mcintyre P.B., Moore J.W., Anderson J.T., Taylor B.W. \& Hall R.O. (2010) Migratory fishes as material and process subsidies in riverine ecosystems. American Fisheries Society Symposium, 73, 550-592. 
Foote K.G. (1987) Fish target strengths for use in echo integrator surveys. Journal of the Acoustical Society of America, 82, 981-987.

Frid A., Burns J., Baker G.G. \& Thorne R.E. (2009) Predicting synergistic effects of resources and predators on foraging decisions by juvenile Stellar sea lions. Oecologia, 158, 775786.

Frouzova J., Kubecka J., Balk H. \& Frouz J. (2005) Target strength of some european fish species and its dependence on fish body parameters. Fisheries Research, 75, 86-96.

Grecay P.A. \& Stierhoff K.L. (2002) A device for simultaneously controlling multiple treatment levels of dissolved oxygen in laboratory experiments. Journal of Experimental Marine Biology and Ecology, 280, 53-62.

Hartman K.J. \& Nagy B.W. (2005) A target strength and length relationship for striped bass and white perch. Transactions of the American Fisheries Society, 134, 375-380.

Hawley N., Johengen T.H., Rao Y.R., Ruberg S.A., Beletsky D., Ludsin S.A. et al. (2006) Lake Erie hypoxia prompts Canada-U.S. study. EOS, Transactions, American Geophysical Union, 87, 313-315.

Hays G.C., Farquhar M.R., Luschi P., Teo S.L.H. \& Thys T.M. (2009) Vertical niche overlap by two ocean giants with similar diets; Ocean sunfish and leatherback turtles. Journal of Experimental Marine Biology and Ecology, 370, 134-143.

Hayward R.S., Margraf F.J., Parrish D.L. \& Vondracek B. (1991) Low-cost field estimation of yellow perch daily ration. Transactions of the American Fisheries Society, 120, 589-604.

Hazen E.L., Craig J.K., Good C.P. \& Crowder L.B. (2009) Vertical distribution of fish biomass in hypoxic waters on the Gulf of Mexico shelf. Marine Ecology-Progress Series, 375, 195-207.

Hergenrader G.L. \& Hasler A.D. (1966) Diel activity and vertical distribution of yellow perch (Perca flavescens) under the ice. Journal of the Fisheries Research Board of Canada, 23, 499-509.

Johnson B.L., Keevin T.M., Laux E.A., Miller T.B., Degan D.J. \& Schaeffer D.J. (2005) Seasonal fish densities in the lock chamber at lock and dam 25, upper Mississippi River. In: Upper Mississippi River-Illinois Waterway System Navigation Study. (Ed. U.S.A.C.O. Engineers), pp. 20. U.S. Army Corps of Engineers, St. Louis, MO.

Kramer D.L. (1987) Dissolved oxygen and fish behavior. Environmental Biology of Fishes, 18, 81-92.

Kraus R.T. \& Rooker J.R. (2007) Patterns of vertical habitat use by Atlantic blue marlin (Makaira nigricans) in the Gulf of Mexico. Gulf and Caribbean Research, 19, 89-97.

Landsman S.J., Nguyen V.M., Gutowsky L.F.G., Gobin J., Cook K.V., Binder T.R. et al. (2011) Fish movement and migration studies in the Laurentian Great Lakes: research trends and knowledge gaps. Journal of Great Lakes Research, 37, 365-379.

Ludsin S.A., Mason D.M., Zhang X., Brandt S.B., Roman M.R., Boicourt W. et al. (2009) Hypoxia-avoidance by planktivorous fish in Chesapeake Bay: implications for food web interactions and fish recruitment. Journal of Experimental Marine Biology and Ecology, 381, S121-S131.

Nathan R. (2008) An emerging movement ecology paradigm. Proceedings of the National Academy of Sciences of the United States of America, 105, 19050-19051.

Parker-Stetter S.L., Rudstam L.G., Sullivan P.J. \& Warner D.M. (2009) Standard operating procedures for fisheries acoustic surveys in the Great Lakes. Great Lakes Fishery Commission Special Publication, 01.

Pihl L. (1994) Changes in the diet of demersal fish due to eutrophication-induced hypoxia in the Kattegat, Sweden. Canadian Journal of Fisheries and Aquatic Sciences, 51, 321-336.

Pollock M.S., Clarke L.M.J. \& Dube M.G. (2007) The effects of hypoxia on fishes: from ecological relevance to physiological effects. Environmental Reviews, 15, 1-14.

Pothoven S.A., Vanderploeg H.A., Ludsin S.A., Höök T.O. \& Brandt S.B. (2009) Feeding ecology of emerald shiners and rainbow smelt in central Lake Erie. Journal of Great Lakes Research, 35, 190-198.

Prince E.D. \& Goodyear C.P. (2006) Hypoxia-based habitat compression of tropical pelagic fishes. Fisheries Oceanography, 15, 451-464.

Rahel F.J. \& Nutzman J.W. (1994) Foraging in a lethal environment: fish predation in hypoxic water of a stratified lake. Ecology, 75, 1246-1253.

Roberts J.J., Höök T.O., Ludsin S.A., Pothoven S.A., Vanderploeg H.A. \& Brandt S.B. (2009) Effects of hypolimnetic hypoxia on foraging and distributions of Lake Erie yellow perch. Journal of Experimental Marine Biology and Ecology, 381, S132-S142.

Roberts J.J., Brandt S.B., Fanslow D., Ludsin S.A., Pothoven S.A., Scavia D. et al. (2011) Effects of hypoxia on consumption, growth, and RNA:DNA ratios of young yellow perch. Transactions of the American Fisheries Society, 140, 1574-1586.

Rose K.A. (2000) Why are quantitative relationships between environmental quality and fish populations so elusive? Ecological Applications, 10, 367-385.

Rose K.A., Adamack A.T., Murphy C.A., Sable S.E., Kolesar S.E., Craig J.K. et al. (2009) Does hypoxia have populationlevel effects on coastal fish? Musing from the virtual world. Journal of Experimental Marine Biology and Ecology, 381, S188-S203.

Rosen R. (1981) Length-dry weight relationships of some freshwater zooplankton. Journal of Freshwater Ecology, 1, 225-229.

Rucinski D.K., Beletsky D., Depinto J.V., Schwab D.J. \& Scavia D. (2010) A simple 1-dimensional, climate based dissolved oxygen model for the central basin of Lake Erie. Journal of Great Lakes Research, 36, 465-476.

Rudstam L.G., Parker S.L., Einhouse D.W., Witzel L.D., Warner D.M., Stritzel J.L. et al. (2003) Application of in situ target-strength estimations in lakes: example from rainbow-smelt surveys in Lake Erie and Champlain. ICES Journal of Marine Science, 60, 500-507. 
Rudstam L.G., Parker-Stetter S.L., Sullivan P.J. \& Warner D.M. (2009) Towards a standard operating procedure for fishery acoustic surveys in the Laurentian Great Lakes, North America. ICES Journal of Marine Science, 66, 1-7.

Ryan P.A., Knight R., Macgregor R., Towns G., Hoopes R. \& Culligan W. (2003) Fish-community goals and objectives for Lake Erie. Great Lakes Fishery Commission Special Publication 03-02, 56.

Sawada K., Furusawa M. \& Williamson N.J. (1993) Conditions for the precise measurement of fish target strength in situ. Journal of the Marine Acoustical Society of Japan, 20, 73-79.

Schaefer K.M., Fuller D.W. \& Block B.A. (2007) Movements, behaviour, and habitat utilization of yellowfin tuna (Thunnus albacares) in the northeastern Pacific Ocean, ascertained through archival tag data. Marine Biology, 152, 503-525.

Schaeffer J.S., Haas R.C., Diana J.S. \& Breck J.E. (1999) Field test of two energetic models for yellow perch. Transactions of the American Fisheries Society, 128, 414-435.

Stanley D.R. \& Wilson C.A. (2004) Effect of hypoxia on the distribution of fishes associated with a petroleum platform off coastal Louisiana. North American Journal of Fisheries Management, 24, 662-671.

Stierhoff K.L., Targett T.E. \& Grecay P.A. (2003) Hypoxia tolerance of the mummichog: the role of access to the water surface. Journal of Fish Biology, 63, 580-592.

Stierhoff K.L., Targett T.E. \& Miller K. (2006) Ecophysiological responses of juvenile summer and winter flounder to hypoxia: experimental and modelling analyses of effects on estuarine nursery quality. Marine Ecology Progress Series, 325, 255-266.

Stierhoff K.L., Targett T.E. \& Power J.H. (2009) Hypoxiainduced growth limitation of juvenile fishes in an estuarine nursery: assessment of small-scale temporal dynamics using RNA:DNA. Canadian Journal of Fisheries and Aquatic Sciences, 66, 1033-1047.

Strand E., Jorgensen C. \& Huse G. (2005) Modelling buoyancy regulation in fishes with swimbladders: bioenergetics and behaviour. Ecological Modelling, 185, 309-327.

Suthers I.M. \& Gee J.H. (1986) Role of hypoxia in limiting diel spring and summer distribution of juvenile yellow perch (Perca flavescens) in a prairie marsh. Canadian Journal of Fisheries and Aquatic Sciences, 43, 1562-1570.

Taylor J.C. \& Rand P.S. (2003) Spatial overlap and distribution of anchovies (Anchoa spp.) and copepods is a shallow stratified estuary. Aquatic Living Resources, 16, 191-196.

Taylor J.C., Rand P.S. \& Jenkins J. (2007) Swimming behaviour of juvenile anchovies (Anchoa spp.) in an episodically hypoxic estuary: implications for individual energetics and trophic dynamics. Marine Biology, 152, 939-957.
Turner R.E. (2001) Some effects of eutrophication on pelagic and demersal marine food webs. In: Coastal Hypoxia: Consequences for Living Resources and Ecosystems. (Eds N.N. Rabalais \& R.E. Turner), pp. 371-398. American Geophysical Union, Washington DC.

Tyson J.T., Johnson T.B., Knight C.T. \& Bur M.T. (2006) Intercalibration of research survey vessels on Lake Erie. North American Journal of Fisheries Management, 26, 559-570.

Vanderploeg H.A., Ludsin S.A., Cavaletto J.F., Höök T.O., Pothoven S.A., Brandt S.B. et al. (2009a) Hypoxic zones as habitat for zooplankton in Lake Erie: refuges from predation or exclusions zones? Journal of Experimental Marine Biology and Ecology, 381, S108-S120.

Vanderploeg H.A., Ludsin S.A., Ruberg S.A., Höök T.O., Pothoven S.A., Brandt S.B. et al. (2009b) Hypoxia affects spatial distributions and overlap of pelagic fish, zooplankton, and phytoplankton in Lake Erie. Journal of Experimental Marine Biology and Ecology, 381, S92-S107.

Wannamaker C.M. \& Rice J.A. (2000) Effects of hypoxia on movements and behaviour of selected estuarine organisms from the southeastern United States. Journal of Experimental Marine Biology and Ecology, 249, 145-163.

Zhang H., Ludsin S.A., Mason D.M., Adamack A.T., Brandt S.B., Zhang X. et al. (2009) Hypoxia-driven changes in the behavior and spatial distribution of pelagic fish and mesozooplankton in the northern Gulf of Mexico. Journal of Experimental Marine Biology and Ecology, 381, s80-s91.

\section{Supporting Information}

Additional Supporting Information may be found in the online version of this article:

Figure S1. Mean (+SE) zooplankton (a) and benthic macroinvertebrate (b) biomass at sites sampled in Lake Erie during August and September 2007.

Table S1. Summary of yellow perch total length (TL) and species composition at sites sampled in Lake Erie's central basin during 2007, where BTR represents bottom trawl and MTR represent mid-water trawl.

As a service to our authors and readers, this journal provides supporting information supplied by the authors. Such materials are peer-reviewed and may be re-organised for online delivery, but are not copyedited or typeset. Technical support issues arising from supporting information (other than missing files) should be addressed to the authors.

(Manuscript accepted 16 January 2012) 